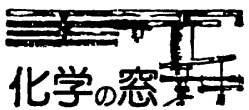

\section{農薬のエナンチオトピック 代謝反応と活性}

生物は本来, 光学活性素材から構築されているとい兄 る. したがって, 農薬の生理活性発現やその代謝が生物 の分子不斉に基本的に依存していることは明らかであ る.たとえば，殺虫活性を有する天然ピレスロイドと同 じ絶対構造を有する光学活性アレスリン（1）は，その鏡 像体よりも圧倒的に強い殺虫活性を示す(1)．また，筆者 らの手がけた光学活性環状ジェン化合物でも，眓示した 絶対構造を有する(十)-クロールデン (2) およびその酸 化物である(ー)ークロールデンエポキシド（3）は殺虫 活性を示すが，それらの 鏡像体にはまったく活性がな (2).

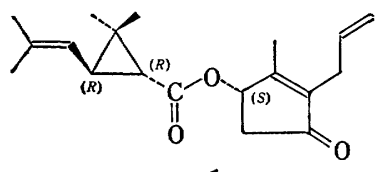

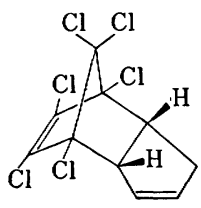

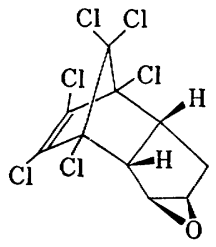

3
以上は，殺虫活性が分子の絶対構造に依存している例 であるが，天然農薬は別として，従来の合成農薬には分 子不斉を有する化合物の数は少なかった。これは，農薬 のドラッグデザインにおいてその基本構造を官能基（た とえばリン酸エステル，カーバメート，アミド結合な ど）を中心に組み立ててきたためであるう。

乙かし，キラルでなくても，エナンチオトピック（置 換基のうちの 1 つを別の置換基に置き代えるとキラルに なる）な構造を有する農薬は比較的多い，対称性構造を
有する $\gamma$-BHC は脱塩酸によって対称性を失い, キラ ルなペンタクロロシクロヘキセンに代謝され(3)，また phorate（4）のようなイオウ原子を含む化合物では，エ チルチオェーテルのイオウ原子は生体内酸化酵素によっ て安定でより活性の強いキラルなスルホキシドに変換さ れる(4)。このように, 農薬がエナンチオトピック代謝反 応によってキラルな化合物に代謝変換される可能性は, 他の農薬についても充分考兄られところである．事 実, 環状ジェン殺虫剤ディルトリン（5）のウサギを用<smiles>CCO[AsH2]=S</smiles>

\section{4}

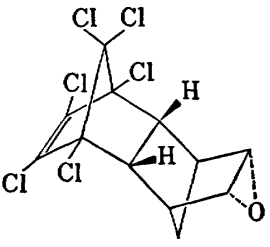

5

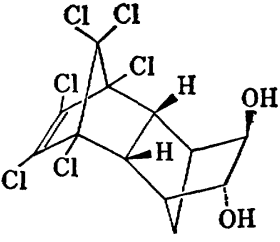

いた代謝実験厄和いて, 比旋光度 $-17.3^{\circ}$ の光学活性卜 ランスーアルドリンジオール（6）の生成が報告されてい る(5)(代謝物 6 の光学純度および絶対構造については明 らかにされていない).

ところで，現在殺蛴として広く使用されている農薬 に, フェニトロチオン(商品名スミチオン) (7) がある. 7 の分子には分子不斉がないが，哺乳動物と昆虫のグル タチオン-S-トランスフェラーゼによってデスメチルフ エニトロチオン（8）に代謝され，不活性化（解毒化）さ れる. その反応に打いて, 7 のもつ 2 個の $\mathrm{OCH}_{3}$ 基は生 物により立体的に区別されて, 光学活性 8 の生成するこ とが予想できる．そこで，以下に，筆者らがこれを確か めるために行なったマウス捄よび昆虫を用いた代謝実験 について紹介しょう。

まず，マウスを用いて 7 を代謝（in vitro および in vivo）させたところ，予期したと打り一方の光学活性 8 が他方より多く生成した（生成比は扩よそ $2: 1$ ). 両鏡 像体は, 代謝生成物 8 を塩素化 $\left(\mathrm{PCl}_{5} / \mathrm{CHCl}_{3}\right)$ 後,

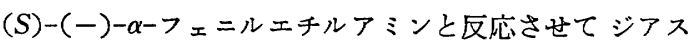
テレオマー（9 および 10） に導き，HPLC（カラム： 


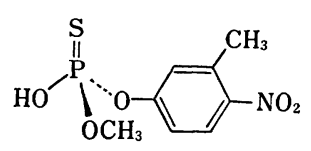

CHO

$(R)_{\mathrm{p}}-(+)-8$

7<smiles>COP(O)(=S)Oc1ccc([N+](=O)[O-])c(C)c1</smiles>

$(S)_{\mathrm{p}}-(-)-8$
Zorbax SIL, 溶出溶媒 : 酢酸 エチルーnーヘキサン (5： 95)）で分離・分析した.

次に, 代謝生成物 8 の絶対構造を決定するため, 合成 によって得られたラセミ型 8 のモノクロリデートから 9 および 10 を調製し，両者を完全に分離した，両者のプ ロトン NMR スペクトルにおいて特徽的に異なるプロ トンは $\delta 3.78$ (9) と 3.53 (10) に現われる $\mathrm{OCH}_{3}$ の シグナルであった. この化学シフトの差 $(0.25 \mathrm{ppm})$ は 明らかに $(S)-\alpha-7_{ェ}$ ニルェチルアミン部分のベンゼン 環のアニソトロピーによるものと考えることができるこ

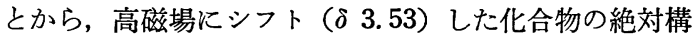
造を $\mathrm{OCH}_{3}$ とベンゼン環が同じ側（紙面の裏側）に位置 する構造，すなわち図示した絶対構造を有する 10 と決 定した. したがって，もら 1 つの化合物の絶対構造は 9 となる.このことは， 絶対構造既知のシアノフェンホ ス $^{(6)}$ の誘導体から 得られた 絶対構造既知のジアステレ オマー(11 および 12)のプロトン NMR スペクトルに 扎いて, 12 の $\mathrm{OCH}_{2} \mathrm{CH}_{3}$ の化学シフトが 11 のそれより 高磁場シフトしたことによってサポートされた. 8 から ジアステレオマーへの 2 段階の誘導反応，すなわち塩素 化とアミデートの生成反応はいずれも反転を伴らことが 明らかにされていることから，デスメチル体とアミデー トの絶対構造は同じことになり，8 の絶対構造と旋光性 を $(R)_{\mathrm{p}}-(+),(S)_{\mathrm{p}}-(-)$ と決定した. したがって, 、 ウスによる 7 から 8 への代謝分解は $(R)_{\mathrm{p}}$ 型が主生成 物であり， $(S)_{\mathrm{p}}$ 型も部分的に 代謝される立体選択的脱 メチル化反応であることがわかった(7).<smiles>COP(=S)(NC(C)c1ccccc1)Oc1ccc([N+](=O)[O-])c(C)c1</smiles>

9<smiles>CO[P+](=S)N[C@H](C)c1ccccc1</smiles>

10

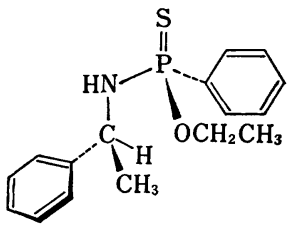

11<smiles>CCOP(=S)(NC(C)c1ccccc1)c1ccccc1</smiles>

12
一方, 昆虫による本反応の立体選択性はどうであろう か. 特に 7 に対してまだ感受性を有する屁虫と，すでに 抵抗性を獲得した昆虫による代謝反応に差があるか否か は興味ある問題である。つまり，本来の昆虫は選択性を 有していたが，農薬を多く使用した結果淘汰され生き残 った抵抗性系統にはすでに立体選択性がなくなった可能 性も考学らるからである，そこで，昆虫としてイェバ エの感受性（Lab-em-7-em, $\mathrm{LD}_{50} 0.12 \mu \mathrm{g} / \mathrm{g}$ ) および抵 抗性（夢の島 '81 系, $\mathrm{LD}_{50} 14 \mu \mathrm{g} / \mathrm{g}$ ) の両系統を用い, $\mathrm{CH}_{3} \mathrm{O}$ の ${ }^{14} \mathrm{C}$-標識 7 を局所施用した。代謝生成物 8 を 含むフラクションを前述の方法でジアステレオマーに誘 導し，9 と 10 をシリカゲル TLC (展開溶媒 : ジェチル エーテルーnーヘキサン $(1: 4))$ で完全分離した後, 各々 を液シンで定量した。そその結果は予想に反し，両系統と も 9 と 10 の生成比には有意な差は認められず, 立体選 択的脱メチル化反応は起こらなかった ${ }^{(8)}$.

このように，フェニトロチオンの生体内脱メチル化反 応は, 哺乳動物では立体選択性があり, 昆虫にはないこ とが明らかとなった. 一方, ブタ肝の酵素を用いた $O$, $O$-dimethyl $O$-1-naphthyl-phosphorothioate の脱メチ ル化反応では, 筆者らの研究に比べ高い選択性（約 9 : 1）が観察されており ${ }^{(9)}$ ，立体選択性は生物種に大きく依 存していることがわかる.

ところで, 農薬の代謝に関与する酵素は, グルタチオ ンーSートランスフェラーゼ以外にいくつもある. ミクロ 
ゾーム酸化酵素もその 1 つであり，スルホキシドの生成

は一種の活性化反応である. Le Patourel と Wright ${ }^{(10)}$ は線虫 (Panagrellus redivivus と Aphelenchus avenae) と微生物 (Bacillus megaterium と Aspergillus niger) に よって phorate (4) が光学活性 phorate sulfoxide (13)<smiles>CCOC(=S)CS(=O)(=O)CC</smiles>

13

に代謝されることを報告した. 特に興味深いのは, 線虫 からの代謝物 13 は負の CD 吸収 ( 220 nm) を与え, 他方, 微生物からの 13 は正の CD 吸収 ( 220 nm) を 示すことである. 13 の両鏡像体の 絶対立体化学および 生物活性については不明であるが，これらの事実は選択 毒性の高い農薬の研究に何らかのヒントを与えるものと 思われる。
おわりに，本研究の遂行にあたり終始ご指導いただきました名 古屋大学農学部 丸茂晋吾教授に深く感謝いたします.

1) 吉岡宏輔, 宮本純之: 化学と生物, 14, 427 (1976).

2) A. Myazaki, T.Hotta, S. Marumo \& M.Saka1 $: J$. Agric. Food Chem., 26, 975 (1978).

3) K. Tanaka, N. Kurihara \& M. Nakajima : Pestic. Biochem. Physiol., 6, 392 (1976).

4) J.S. Bowman \& J.E. Casida : J. Econ. Entomol., 51, 838 (1958).

5) F. Korte \& H. Arent: Life Sci., 4, 2017 (1965).

6) H. Ohkawa : "Insecticide Mode of Action", ed. by J. R. Coats, Academic Press, 1982, p. 163.

7) A. Miyazaki, M. Kawaradani, S. Marumo \& C. Tomizawa : J. Pesticide Sci., 8, 115 (1983).

8）瓦谷光男, 宮崎昭雄, 浜田昌之, 中鉢光雄, 丸茂晋吾 : 日 本農薬学会第 8 回大会講演要旨集, 104 (1983).

9) C. Donninger : Bull. W. H.O., 44, 265 (1971).

10) G. N. J.Le Patourel \& D. J. Wright : Comp. Biochem. Physiol. C, 53, 73 (1976).

（宮崎 昭雄, 大阪府農林技術センタ一）

プロフィル

前島 正義 (Masayoshi Maeshıma) 昭和 29 年 1 月 27 日生 $<$ 略歴 $>$ 昭和 51 年名 古屋大学農学部農芸化学科卒業 $/ 56$ 年同 大学大学院農学研究科博士課程修了 (生 物化学) $/ 57$ 年日本学術振與会 奨励研究 員, 現在同大学大学院研究生<研究テー マと抱負>高等植物ミトコンドリアの電 子伝達系成分の構造と機能および生合成 に関する研究. まず研究職に就くことが 目骠です

町田 武生 (Takeo Machida) 昭和 18 年 9 月 4 日生 $<$ 略歴 $>$ 昭和 42 年東京大 学理学部生物学科卒業 $/ 47$ 年同大学大学 院理学研究科博士課程修了/同年東京都 老人総合研究所研究員 $/ 53$ 年鹿児島大学 理学部助教授 $/ 57$ 年広島大学理学部助教 授, 現在にいたるく研究テーマと抱負〉 加龄と内分泌, 出生前後のホルモン環境 のちがいがその後の内分件機能におよ注 寸影響

丸茂 晋吾 (Shingo Marumo) Vol.
14 , No. 5 , p. 309 参照

宮崎 昭雄 (Akio Miyazaki) 昭和 16年 9 月 23 日生 <略歴>昭和 39 年名古屋 大学農学部農芸化学科卒業/同年同大学 農学部勤務 $/ 45$ 年大阪府農林技術センタ 一研究員, 現在にいたるく研究テーマと 抱負 >農薬の光学活性之生物活性<趣 味>魚釣り，スポーツ

森内 幸子 (Sachiko Moriuch1) 昭 和12年 8 月 3 日生<略歴>昭和38年東京 女子医科大学卒業 $/ 43$ 年東京大学大学院 医学系研究科修了(医博) /同年同大学医 学部助手 $/ 53$ 年同講師 $/ 54$ 年日本女子大 学助教授, 現在にいたる.この間, 46〜 49年米国ウィスコンシン大学, フランス ネッカー小児病院に留学く研究テーマと 抱負>オステオカルシンに関する研究, 消化吸収に関する研究く趣味〉旅行

山口 昌哉 (Masaya Yamaguti) 大 正14年 2 月 3 日生 <略歴>昭和 22 年京都
帝国大学理学部数学科卒業 $/ 23$ 年同大学 理学部助手 $/ 24$ 年同大学工学部助手 $/ 25$ 年同講師 $/ 26$ 年同助教授 $/ 36$ 年同教授 $/$ 43 年同大学理学部教授 $/ 56$ 年同理学部長 (〜58年), 現在にいたるく研究テーマと 抱負〉非線型問題く趣味〉山野ホーコー とスケッチ

吉岡 宏輔 (Hirosuke Yoshıoka) 昭和 8 年 3 月 19 日生 $<$ 略歴>昭和 31 年東 京大学医学部薬学科卒業/同年住友化学 工業(株)入社 $/ 37$ 年東京大学農学部研究 生 (有機化学) $/ 46$ 年住友化学生物科学 研究所主任研究員 $/ 53$ 年同主席研究員, 現在にいたる．この間，42年米国テキサ ス州立大学植物 化学 研究室博士研究員 く研究テーマと抱負〉有機化学を基盤と して新しい機能性物質を創り出すこと, 天然物起源の素材の特質を活かした応用 的展開く趣味 $>$ DIY, 音楽 (聴くこと), 読書 (ただし専門分野外の科学) 